DOI: https://doi.org/10.12797/Politeja.15.2018.54.14

Ewa KAMARAD

Uniwersytet Jagielloński

ewa.kamarad@uj.edu.pl

\title{
WPEYW TRAKTATU LIZBOŃSKIEGO NA UNIJNE PRAWO PRYWATNE MIĘDZYNARODOWE
}

ABSTRACT The impact of the Treaty of Lisbon on the EU private international law The paper deals with private international law after the adoption of the Treaty of Lisbon. In particular, it discusses the legal basis for adopting secondary legislation in this field and the EU competence to conclude international agreements. Next, the EU legislative activity is presented, with particular emphasis on family law, in which enhanced cooperation has already been initiated twice.

Keywords: private international law, Treaty of Lisbon, EU competence, ordinary legislative procedure, special legislative procedure

Słowa kluczowe: prawo prywatne międzynarodowe, traktat lizboński, kompetencje UE, zwykła procedura ustawodawcza, specjalna procedura ustawodawcza 


\begin{abstract}
A rtykuł ma na celu przybliżenie działań podejmowanych przez UE w dziedzinie $A_{\text {prawa prywatnego międzynarodowego oraz ocenę wpływu traktatu lizbońskiego }}$ na te działania. Biorąc pod uwagę brzmienie przepisów traktatowych upoważniających instytucje unijne do przyjmowania aktów prawa wtórnego dotyczących prawa prywatnego międzynarodowego, ich zamieszczenie w traktacie reformującym należy ocenić jako kontynuację procesu przekazywania UE kompetencji w tej dziedzinie prawa. Proces ten nie jest jednak bynajmniej zakończony, jako że przewidziana w traktacie lizbońskim specjalna procedura ustawodawcza dla przyjęcia aktu prawnego odnoszącego się do spraw rodzinnych o transgranicznym charakterze wymaga osiągnięcia przez państwa członkowskie jednomyślności w tym zakresie, co - jak wynika z obserwacji prac unijnego legislatora w ostatnich latach - stanowi duży problem i w praktyce przeszkodę do ujednolicenia prawa prywatnego międzynarodowego w skali wszystkich 28 państw członkowskich.
\end{abstract}

Przed przyjęciem traktatu lizbońskiego postanowienia dotyczące prawa prywatnego międzynarodowego były częścią Tytułu IV (Wizy, azyl, imigracja i inne polityki zwiazane ze swobodnym przeptywem osób) Traktatu o Wspólnocie Europejskiej (TWE)1. Zgodnie z art. 65 TWE instytucje WE mogły podejmować środki z zakresu współpracy sądowej w sprawach cywilnych, mające skutki transgraniczne i zmierzające m.in. do poprawy oraz uproszczenia uznawania i wykonywania orzeczeń w sprawach cywilnych i handlowych, a także do wspierania zgodności norm mających zastosowanie w państwach członkowskich w dziedzinie kolizji ustaw i sporów o właściwość. Środki te mogły być podejmowane w zakresie niezbędnym do zapewnienia należytego funkcjonowania rynku wewnętrznego.

Procedura przyjmowania środków dotyczących prawa prywatnego międzynarodowego zastała określona w art. 67 TWE. Przewidywał on, że od 1 maja 2004 r. środki te miały być przyjmowane przez Radę na wniosek Komisji. Państwa członkowskie miały w tym zakresie pośrednią inicjatywę ustawodawczą ${ }^{2}$ gdyż mogły żądać od Komisji przedłożenia odpowiedniego wniosku Radzie. Środki te były przyjmowane przez Radę zgodnie z procedurą współdecydowania określoną w art. 251 TWE, a więc Rada przyjmowała je, stanowiąc większością kwalifikowaną wspólnie z Parlamentem Europejskim. W art. 67 ust. 5 TWE przewidziano odstępstwo od tej procedury w przypadku, gdy przyjmowany środek dotyczył prawa rodzinnego - wówczas w Radzie wymagana była jednomyślność.

W obowiązującym stanie prawnym, po przyjęciu traktatu lizbońskiego ${ }^{3}$ współpraca sądowa w sprawach cywilnych jest regulowana w rozdziale 3 TFUE ${ }^{4}$. W art. 81 TFUE,

Traktat ustanawiający Wspólnotę Europejską (wersja skonsolidowana), Dz.U. UE C 321, 29 XII 2006.

Wcześniej, w okresie przejściowym od 1 V 1999 r. do 1 V 2004 r., państwa członkowskie miały bezpośrednią inicjatywę ustawodawczą.

3 Dz.U. UE C 306, 17 XII 2007.

4 Traktat ofunkcjonowaniu Unii Europejskiej (wersja skonsolidowana), Dz.U. UE C 326, 26 X 2012. 
będącym odpowiednikiem art. 65 TWE, określono kompetencje UE w tej materii. Ustęp 1 stanowi, że Unia rozwija współpracę sądową w sprawach cywilnych mających skutki transgraniczne, w oparciu o zasadę wzajemnego uznawania orzeczeń sądowych i pozasądowych. W ramach tej współpracy mogą być przyjmowane środki, których celem jest zbliżenie przepisów ustawowych i wykonawczych państw członkowskich, w tym zapewnienie zgodności norm mających zastosowanie w państwach członkowskich w przypadku kolizji przepisów i sporów o właściwość oraz wzajemnego uznawania i wykonywania przez państwa członkowskie orzeczeń sądowych i pozasądowych. Środki te, zgodnie z ust. 2, mogą być przyjmowane przez Parlament Europejski i Radę w zwykłej procedurze ustawodawczej, w szczególności jeżeli jest to niezbędne do prawidłowego funkcjonowania rynku wewnętrznego. Wyjątkiem są środki dotyczące prawa rodzinnego mające skutki transgraniczne, które wedle ust. 3 są ustanawiane przez Radę stanowiącą zgodnie ze specjalną procedurą ustawodawczą, w której Rada stanowi jednomyślnie po konsultacji z Parlamentem Europejskim. Rola Parlamentu jest więc ograniczona w porównaniu z procedurą, w której przyjmowane są instrumenty dotyczące prawa prywatnego międzynarodowego $w$ innych dziedzinach niż prawo rodzinne.

Warto przy tym wyraźnie zaznaczyć, że kompetencja przyznana Unii w art. 81 TFUE nie obejmuje prawa materialnego. Dotyczy to również ust. 3 tegoż artykułus. Ponadto wykładnia pojęcia prawa rodzinnego ma na gruncie prawa unijnego charakter autonomiczny ${ }^{6}$. Jeśli natomiast akt prawny przyjmowany w ramach współpracy sądowej w sprawach cywilnych dotyczyłby różnych dziedzin prawa, w tym prawa rodzinnego, to przyjęcie całego instrumentu podlegałoby specjalnej procedurze ustawodawczej przewidzianej w art. 81 ust. 3 TFUE.

Artykuł 81 TFUE, podobnie jak poprzednie regulacje traktatowe stanowiące podstawę do przyjmowania przez UE regulacji w dziedzinie prawa prywatnego międzynarodowego, mówi ogólnie o „środkach”. Oznacza to, że z formalnego punktu widzenia możliwe jest przyjęcie w tej materii każdego środka określonego w art. 288 TFUE, który jest przyjmowany w zwykłej lub w specjalnej procedurze ustawodawczej, a więc rozporządzenia, dyrektywy lub decyzji ${ }^{7}$.

Instrumenty przyjmowane na podstawie art. 81 TFUE mogą dotyczyć jedynie spraw cywilnych. Z zakresu kompetencji UE są więc wyłączone sprawy karne, administracyjne, a także publiczne, $w$ tym podatkowe i celne.

Ponadto art. 81 TFUE reguluje współpracę sądową w sprawach cywilnych mających skutki transgraniczne, a więc $\mathrm{w}$ tym zakresie nie mogą być przyjmowane środki dotyczące spraw wyłącznie krajowych. Warto przy tym wskazać, że treść art. 81 różni się w tym zakresie od obowiązującego uprzednio art. 65 TWE. Pierwszy mówi o sprawach

P. Mostowik, Kwestie kompetencji Unii Europejskiej oraz warunków pomocniczości i proporcjonalności prawodawstwa unijnego na tle projektów rozporządzeń o jurysdykcji, prawie wtaściwym i skuteczności zagranicznych orzeczeń w majątkowych sprawach matżenskich i partnerskich, „Zeszyty Prawnicze Biura Analiz Sejmowych" 2011, nr 3, s. 27-29.

6 Na temat pojęcia „europejskiego prawa rodzinnego” zob. P. Mostowik, Wtadza rodzicielska i opieka nad dzieckiem w prawie prywatnym międzynarodowym, Kraków 2014, s. 40.

J. Osiejewicz, Harmonizacja prawa państw cztonkowskich Unii Europejskiej, Warszawa 2016, s. 141. 
cywilnych mających skutki transgraniczne, drugi - o środkach mających skutki transgraniczne. Różnica ta nie ma, co prawda, wpływu na kształt unijnych kompetencji w tym zakresie $^{8}$, jednak wydaje się, że sformułowanie zmienione przez traktat lizboński jest bardziej odpowiednie, bowiem to sprawy cywilne z elementem obcym, a więc mające skutki transgraniczne, implikują konieczność przyjmowania instrumentów prawnych dotyczących współpracy sądowej. Te instrumenty oczywiście również mają „skutki” transgraniczne - w tym znaczeniu, że dotyczą spraw z elementem obcym - jednak te „skutki” są pochodne względem transgranicznego charakteru sprawy. Wymóg, aby sprawy, których dotyczą regulacje przyjmowane przez UE na gruncie art. 81 TFUE, miały element zagraniczny, jest stosunkowo łatwy do spełnienia w przypadku aktów w dziedzinie prawa prywatnego międzynarodowego. Niemniej jednak w każdym z tych aktów prawnych w przepisach określających ich zakres zastosowania znajduje się wyraźne postanowienie, że dotyczą one spraw powiązanych z prawem różnych państw9 . Wymóg ten ma jednak znaczenie $\mathrm{w}$ przypadku innych zagadnień mieszczących się $\mathrm{w}$ pojęciu współpracy sądowej w sprawach cywilnych, takich jak rozwój alternatywnych metod rozstrzygania sporów, skutecznego dostępu do wymiaru sprawiedliwości oraz usuwania przeszkód utrudniających prawidłowy bieg postępowań cywilnych ${ }^{10}$.

Artykuł 65 TWE stanowił o przyjmowaniu środków $w$ zakresie niezbędnym do zapewnienia należytego funkcjonowania rynku wewnętrznego ${ }^{11}$. Natomiast art. 81 TFUE przewiduje przyjmowanie aktów prawnych w dziedzinie współpracy sądowej w sprawach cywilnych $w$ szczególności jeśli jest to niezbędne do należytego funkcjonowania rynku wewnętrznego. Dodanie sformułowania „w szczególności”, zdaniem większości przedstawicieli doktryny, nie ma jedynie charakteru zmiany redakcyjnej. Wręcz przeciwnie: oznacza, że w obecnym stanie prawnym wymóg niezbędności przyjmowanych środków do właściwego funkcjonowania rynku wewnętrznego nie jest już warunkiem koniecznym rozpoczęcia procedury legislacyjnej. Zdaniem Karola Weitza oznacza to, że po przyjęciu traktatu lizbońskiego nastąpiło rozerwanie problematyki współpracy sądowej w sprawach cywilnych z kategorią swobodnego przepływu osób ${ }^{12}$.

Kompetencja w dziedzinie współpracy sądowej w sprawach cywilnych ma charakter dzielony ${ }^{13}$. Zgodnie z zasadą „zajętego pola” w przypadku, gdy Unia wykona

8 K. Weitz, Komentarz do art. 81, [w:] Traktat of funkcjonowaniu Unii Europejskiej. Komentarz, t. 1, red. A. Wróbel, Warszawa 2012, s. 1178.

9 Zastrzeżenie to wynika z faktu, że choć wydaje się, iż normy kolizyjne muszą - ze swej natury - dotyczyć spraw powiązanych z prawem więcej niż jednego państwa, to sama ich konstrukcja powoduje, że wskazują one prawo właściwe także w przypadku, gdy wszystkie istotne aspekty danej sprawy są zamknięte w granicach jednego państwa. Zob. M. Pazdan, System prawa prywatnego. Tom 20A. Prawo prywatne międzynarodowe, red. tenże, Warszawa 2014, s. 17-18. Podobny problem dotyczy norm jurysdykcyjnych. Zob. K. Weitz, Komentarz..., s. 1179.

10 K. Weitz, Komentarz..., s. 1179.

11 Zob. K. Kowalik, Kompetencja Wspólnoty Europejskiej w zakresie prawa prywatnego międzynarodowego, „Przegląd Sądowy” 2005, z. 2, s. 111-112.

12 K. Weitz, Komentarz..., s. 1177.

13 Tamże, s. 1158. 
przysługujące jej kompetencje, uzyskuje ona w zakresie zastosowania danej regulacji kompetencje wyłączne, pozbawiając jednocześnie państwa członkowskie możliwości samodzielnego działania w tej materiii ${ }^{14}$. Konsekwencją takiego charakteru kompetencji Unii jest możliwość uruchomienia wzmocnionej współpracy w dziedzinie prawa prywatnego międzynarodowego, a także zastosowanie do tej dziedziny zasady pomocniczości oraz zasady proporcjonalności. Ten ostatni aspekt jest szczególnie istotny po przyjęciu traktatu lizbońskiego, który nadał parlamentom narodowym uprawnienie do kontrolowania zgodności proponowanego aktu prawnego z zasadą pomocniczości i proporcjonalności. Jeśli zastrzeżenia w tym zakresie zgłosi odpowiednia liczba parlamentów, wówczas projekt powinien zostać poddany ponownej analizie, co może skutkować jego zmianą lub wycofaniem.

Ważną zmianą wprowadzoną przez traktat lizboński jest poszerzenie jurysdykcji TSUE w dziedzinie współpracy sądowej w sprawach cywilnych. Przed 2009 r. sądy krajowe miały ograniczoną możliwość kierowania do TSUE pytań prejudycjalnych w tej dziedzinie - mogły to robić jedynie te sądy, których orzeczenia zgodnie z prawem wewnętrznym danego państwa członkowskiego nie podlegały zaskarżeniu ${ }^{15}$. Od wejścia w życie traktatu lizbońskiego pytania prejudycjalne dotyczące współpracy sądowej w sprawach cywilnych podlegają ogólnej procedurze z art. 267 TFUE, a więc mogą być zadawane przez wszystkie sądy ${ }^{16}$.

Artykuł 81 ust. 3 TFUE przewiduje możliwość zmiany procedury przyjmowania regulacji unijnych dotyczących współpracy sądowej w sprawach rodzinnych mających skutki transgraniczne na zwykłą procedurę ustawodawczą. Jest to tzw. procedura kładki (passerelle $)^{17}$, pozwalająca na zmianę postanowień traktatowych UE bez konieczności przeprowadzania rewizji zgodnie $\mathrm{z}$ art. 48 TUE. Zmiany te są przeprowadzane na podstawie wyraźnego upoważnienia zamieszczonego w traktatach. Decyzję w tym zakresie podejmują instytucje unijne, w szczególności Rada UE i Rada Europejska. W obecnym stanie prawnym procedura kładki przewidziana jest $\mathrm{w}$ wielu przepisach prawa pierwotnego i ma charakter strukturalny (art. 48 ust. 6 i 7 TUE) albo ad hoc, jeśli odnosi się do poszczególnych dziedzin integracji ${ }^{18}$. Przykładem tej ostatniej jest procedura zamieszczona $\mathrm{w}$ art. 81 ust. 3 TFUE. Zgodnie $\mathrm{z}$ tym przepisem w celu przeprowadzenia uproszczonej zmiany traktatów Komisja Europejska musi sporządzić wniosek, określając w nim zagadnienia należące do prawa rodzinnego, które miałyby być objęte zwykłą procedurą ustawodawczą. Następnie wniosek kierowany jest do Rady UE, która

14 W. Sadowski, M. Taborowski, Wspótpraca sądowa w sprawach cywilnych, Warszawa 2011, s. 10.

15 K. Lubińska, Traktat Lizboński a wspótpraca sądowa w sprawach cywilnych, „Państwo i Prawo” 2008, z. 10 , s. 116.

16 K. Weitz, Komentarz..., s. 1160.

17 W literaturze polskiej stosowane są różne określenia tej procedury: „procedura kładki”, „klauzula pomostowa”, „procedura dynamizująca” oraz „klauzula przejścia”. Zob. J. Barcz, Problem ujednolicenia reżimu prawnego w Przestrzeni Wolności, Bezpieczeństwa i Sprawiedliwości UE - w sprawie art. 42 TUE (tzw. procedura ktadki), „Europejski Przegląd Sądowy” 2006, nr 10, s. 5, przyp. 9.

18 J. Pawlicka, Procedura ktadki jako uproszczony tryb zmiany traktatów stanowiacych podstawe Unii Europejskiej, Warszawa 2017, s. 29-30. 
podejmuje decyzję w tym zakresie jednomyślnie, po konsultacji z Parlamentem. Takie ujęcie procedury kładki ma dwie bardzo istotne konsekwencje. Po pierwsze, zmiana traktatów w tej sprawie nie stanowi remedium na brak jednomyślności w przyjmowaniu konkretnych aktów prawnych w dziedzinie prawa rodzinnego. Po drugie, rola Parlamentu w procedurze zmiany jest, podobnie jak w specjalnej procedurze ustawodawczej, ograniczona jedynie do konsultacji. Dopiero po przeprowadzeniu zmiany za pomocą procedury kładki Parlament uzyskałby realny wpływ na decydowanie o kształcie regulacji w dziedzinie prawa rodzinnego.

W związku z procedurą kładki pojawia się wątpliwość: jak bardzo dokładna powinna być decyzja Rady w tym zakresie. W art. 81 ust. 3 TFUE użyto mało precyzyjnego sformulowania aspekty prawa rodzinnego mające skutki transgraniczne $e^{19}$. Zakładając racjonalność ustawodawcy, należy uznać, że jest to zabieg celowy. Tym samym trzeba przyjąć, że podejmując powyższą decyzję, Rada powinna ograniczyć się do określenia podstawowych wytycznych, natomiast szczegółowe kwestie powinny zostać unormowane w ramach konkretnych aktów prawa wtórnego przyjętych w zwykłej procedurze ustawodawczej ${ }^{20}$.

Nie bez znaczenia na przebieg całego procesu są także przewidziane w art. 81 ust. 3 TFUE uprawnienia parlamentów narodowych państw członkowskich. Zanim wniosek sporządzony przez Komisję trafi do Rady, przekazywany jest parlamentom narodowym, z których każdy może zgłosić sprzeciw w tym zakresie. Dopiero jeżeli żaden z nich w ciągu sześciu miesięcy nie skorzysta z tej możliwości, droga do podjęcia decyzji przez Radę jest otwarta. Kompetencje parlamentów narodowych w tym zakresie przypominają nieco kompetencje Parlamentu Europejskiego w procedurze zgody - mogą one wyrazić zgodę na zmianę albo się jej sprzeciwić, nie mogą natomiast zgłosić żadnych poprawek do sformułowanego przez Komisję wniosku, w szczególności zaś nie mają wpływu na określenie aspektów prawa rodzinnego, których ten wniosek dotyczy. Warto przy tym podkreślić, że możliwość sprzeciwu przyznana parlamentom narodowym dotyczy wyłącznie decyzji o przejściu ze specjalnej procedury ustawodawczej na zwykłą, natomiast nie konkretnych aktów podejmowanych już w tej procedurze ${ }^{21}$.

Analiza wpływu traktatu lizbońskiego na unijne prawo prywatne międzynarodowe nie byłaby pełna bez omówienia zagadnienia kompetencji UE do zawierania umów międzynarodowych w tej dziedzinie. Zdaniem TSUE może ona wynikać nie tylko z wyraźnego przyznania jej w traktatach, lecz także w sposób dorozumiany z innych postanowień prawa pierwotnego oraz aktów wydanych na ich podstawie przez instytucje unijne. Ponadto w swojej linii orzeczniczej, zapoczątkowanej słynnym orzeczeniem w sprawie ERTA ${ }^{22}$, TSUE wypracował zasadę paralelizmu kompetencji zewnętrznych i wewnętrznych WE, zgodnie z którą rodzaj i zakres unijnych kompetencji do zawierania umów międzynarodowych $\mathrm{z}$ innymi podmiotami prawa międzynarodowego

\footnotetext{
Tamże, s. 147.

20 K. Weitz, Komentarz..., s. 1182-1183.

21 Tamże, s. 1183.

22 Wyrok Trybunału z 31 III 1971, C-22/70.
} 
$\mathrm{w}$ danej dziedzinie odpowiada rodzajowi i zakresowi kompetencji WE do wydawania aktów prawa wtórnego skierowanych do państw członkowskich ${ }^{23}$. Oznacza to, że od wejścia w życie traktatu amsterdamskiego UE ma także kompetencje do zawierania umów dotyczących prawa prywatnego międzynarodowego z państwami trzecimi oraz $\mathrm{z}$ innymi organizacjami międzynarodowymi.

Zgodnie z wspomnianym art. 67 ust. 1 i $2 \mathrm{w}$ czasie pięcioletniego okresu przejściowego kompetencje zewnętrzne WE w tej dziedzinie miały charakter dzielony, natomiast po upływie tego okresu stały się jej kompetencjami wyłącznymi. Zostało to potwierdzone przez TSUE w opinii $1 / 03^{24}$, wydanej na wniosek Rady UE w sprawie zawarcia nowej konwencji z Lugano o jurysdykcji, uznawaniu orzeczeń sądowych oraz ich wykonywaniu w sprawach cywilnych i handlowych ${ }^{25}$. Podczas zawierania tej konwencji pojawił się bowiem problem dotyczący charakteru kompetencji WE: wyłącznego bądź dzielonego. Przyjęcie pierwszego rozwiązania w praktyce oznaczało, że państwa członkowskie nie posiadają w tej dziedzinie prawa do zaciągania zobowiązań wobec krajów trzecich, działając zarówno indywidualnie, jak i wspólnie.

Traktat lizboński nie wprowadził w tym zakresie żadnych znaczących zmian. Wartość dodaną stanowi niewątpliwie uregulowanie dotyczące kompetencji zewnętrznych, wprowadzone do prawa pierwotnego. Obecnie kwestia kompetencji zewnętrznych UE jest wyraźnie uregulowana w art. 3 ust. 2 TFUE ${ }^{26}$, który stanowi, że Unia ma także wytączna kompetencje do zawierania umów międzynarodowych, jeżeli ich zawarcie zostato przewidziane w akcie prawodawczym Unii lub jest niezbędne do umożliwienia Unii wykonywania jej wewnętrznych kompetencji.

Wyłączny charakter kompetencji zewnętrznych UE w dziedzinie prawa prywatnego międzynarodowego został ponownie potwierdzony przez TSUE w opinii $1 / 13^{27}$. Sprawa dotyczyła tego, czy zgoda na przystąpienie państwa trzeciego do Konwencji dotyczącej cywilnych aspektów uprowadzenia dziecka za granicę, przyjętej w ramach Haskiej Konferencji Prawa Prywatnego Międzynarodowego ${ }^{28}$, należy do wyłącznej kompetencji Unii Europejskiej, czy też zgodę taką wydają państwa członkowskie. Trybunał orzekł, że choć sama Unia nie jest stroną konwencji, wyrażenie zgody na przystąpienie do niej państwa trzeciego jest wyłączną kompetencją UE.

Korzystając ze swych kompetencji ustawodawca unijny wydał na przestrzeni lat szereg aktów prawnych w dziedzinie prawa prywatnego międzynarodowego. Pierwszym $\mathrm{z}$ nich było rozporządzenie $\mathrm{nr} 44 / 2001 \mathrm{w}$ sprawie jurysdykcji oraz uznawania i wykonywania orzeczeń w sprawach cywilnych (tzw. Bruksela $I)^{29}$ przyjęte 22 grudnia

\footnotetext{
P. Saganek, Komentarz do art. 3, [w:] Traktat o funkcjonowaniu Unii Europejskiej. Komentarz..., s. 201. Opinia z 7 II 2006, C-1/03.

25 Konwencja o jurysdykcji i uznawaniu oraz wykonywaniu orzeczeń sądowych w sprawach cywilnych $i$ handlowych, podpisana w Lugano dnia 30 października 2007 r., Dz.U. UE L 339, 21 XII 2007.

26 Traktat of funkcjonowaniu Unii Europejskiej, Dz.U. UE C 202, 7 VI 2016.

27 Opinia z 14 X 2014.

28 Dz.U. 1995, nr 108, poz. 528.

29 Dz.U. UE L 12, 16 I 2001.
} 
2000 r. Zostało ono zastąpione przez rozporządzenie nr 1215/2012 o tym samym tytule (tzw. Bruksela I bis) ${ }^{30}$, przyjęte 12 grudnia 2012 r. Kolejnym aktem prawnym było rozporządzenie nr 1347/2000, dotyczące jurysdykcji oraz uznawania i wykonywania orzeczeń w sprawach małżeńskich i niektórych sprawach rodzicielskich (tzw. Bruksela II) ${ }^{31}$, przyjęte 29 maja 2000 r., zastąpione rozporządzeniem nr 2201/2003 (tzw. Bruksela II bis) ${ }^{32}$, przyjętym 27 listopada 2003 r.

W odniesieniu do pozostałych kwestii w obrębie prawa prywatnego międzynarodowego, zwłaszcza norm kolizyjnych określających prawo właściwe, unijne plany ustawodawcze zostały przedstawione w przyjętym na szczycie Rady Europejskiej w 2004 r. Programie haskim: Wzmacnianie wolności, bezpieczeństwa i sprawiedliwości w Unii Europejskiej33. Przewidywał on stworzenie do końca 2011 r. sześciu rozporządzeń, dotyczących: zobowiązań umownych, zobowiązań pozaumownych, roszczeń alimentacyjnych, spraw spadkowych, majątkowych ustrojów małżeńskich i rozwodów ${ }^{34}$.

Prace nad wszystkimi rozporządzeniami zostały już zakończone. Dotychczas przyjęto: rozporządzenie nr 864/2007 (tzw. Rzym II), dotyczące prawa właściwego dla zobowiązań pozaumownych ${ }^{35}$; rozporządzenie nr 593/2008 (tzw. Rzym I), dotyczące prawa właściwego dla zobowiązań umownych ${ }^{36}$; rozporządzenie nr 4/2009 (alimentacyjne) ${ }^{37}$; rozporządzenie $\mathrm{nr} 650 / 2012$ (spadkowe) ${ }^{38}$; rozporządzenie $\mathrm{nr}$ 1259/2010, dotyczące rozwodów i separacji ${ }^{39}$; rozporządzenie nr 2016/1103, dotyczące majątkowych ustrojów małżeńskich ${ }^{40}$; rozporządzenie nr 2016/1104, dotyczące skutków majątkowych zarejestrowanych związków partnerskich ${ }^{41}$.

30 Dz.U. UE L 351, 20 XII 2012.

31 Dz.U. UE L 160, 30 VI 2000.

32 Dz.U. UE L 338, 23 XII 2003.

33 Dz.U. UE C 53, 3 III 2005.

34 Kontynuacją Programu haskiego był przyjęty w 2009 r. Program sztokholmski: Otwarta i bezpieczna Europa dla dobra i ochrony obywateli. Dz.U. UE C 115, 4 V 2010.

35 Rozporzadzenie Parlamentu Europejskiego i Rady WE Nr 864/2007 z 11 lipca 2007 r. w sprawie prawa wtaściwego dla zobowiąań pozaumownych, Dz.U. UE L 199, 31 VII 2007.

36 Rozporzadzenie Parlamentu Europejskiego i Rady WE Nr 593/2008 z 17 czerwca 2008 r. w sprawieprawa wtaściwego dla zobowiązań umownych, Dz.U. UE L 177, 4 VII 2008.

37 Rozporządzenie Rady Nr 4/2009 z dnia 18 grudnia 2008 r. w sprawie jurysdykcji, prawa wtaściwego, uznawania i wykonywania orzeczeń oraz wspótpracy w zakresie zobowiązań alimentacyjnych, Dz.U. UE L 7, 10 I 2009.

38 Rozporzadzenie Parlamentu Europejskiego i Rady UE z dnia 4 lipca 2012 r. w sprawie jurysdykcji, prawa wtaściwego, uznawania i wykonywania orzeczeń, przyjmowania i wykonywania dokumentów urzędowych dotyczacych dziedziczenia oraz w prawie ustanowienia europejskiego poświadczenia spadkowego, Dz.U. UE L 201, 27 VII 2012.

39 Rozporzadzenie Rady UE z dnia 20 grudnia 2010 r. w sprawie wprowadzenia w życie wzmocnionej wspótpracy w dziedzinie prawa wtaściwego dla rozwodu i separacji prawnej, Dz.U. UE L 343, 29 XII 2010.

40 Rozporządzenie Rady UE z dnia 24 czerwca 2016 r. wdrażające wzmocniona wspótprace $w$ dziedzinie jurysdykcji, prawa wtaściwego oraz uznawania i wykonywania orzeczeń w sprawach dotyczacych matżeńskich ustrojów majątkowych, Dz.U. UE L 183, 8 VII 2016.

41 Tamże. 
Trzy ostatnie rozporządzenia dotyczą prawa rodzinnego, dlatego do ich przyjęcia wymagane było osiągnięcie jednomyślności w Radzie. W praktyce okazało się to niemożliwe i zostały przyjęte w ramach wzmocnionej współpracy.

W przypadku rozporządzenia nr 1259/2010 w sprawie prawa właściwego dla rozwodu i separacji prawnej państwa członkowskie nie były w stanie wypracować kompromisu w odniesieniu do kształtu norm kolizyjnych. Wynikało to z różnego uregulowania rozwodu w ich materialnym prawie rodzinnym. W czasie prac nad rozporządzeniem Szwecja i Finlandia zgłosiły obawy co do negatywnego wpływu rozporządzenia na uzyskanie rozwodu ${ }^{42}$. W państwach tych możliwość przeprowadzenia rozwodu jest traktowana jako fundamentalne prawo, a rozporządzenie pozwalające na wybór prawa właściwego dla rozwodu, które będzie stosowane zamiast prawa forum, może spowodować przedłużenie procedury rozwodowej ${ }^{43} . \mathrm{Z}$ drugiej strony nie we wszystkich porządkach prawnych państw członkowskich rozwód był uregulowany jako instytucja prawna. Zgodnie z prawem Malty uzyskanie rozwodu nie było w ogóle możliwe, a zarejestrowanie orzeczenia rozwodowego wydanego przez sąd innego państwa było dopuszczalne jedynie wówczas, gdy jedna ze stron postępowania miała obywatelstwo państwa, w którym wydane zostało to orzeczenie lub miała w tym państwie miejsce zamieszkania. Jeżeli te przesłanki nie były spełnione, wówczas orzeczenie rozwodowe nie wywierało zgodnie z prawem Malty skutków prawnych, a osoby rozwiedzione na jego podstawie nie mogły ponownie zawrzeć małżeństwa przed organami maltańskimi. Sytuacja zmieniła się już po przyjęciu rozporządzenia nr 1259/2010. Dnia 28 maja 2011 r. obywatele Malty w powszechnym referendum opowiedzieli się za wprowadzeniem do prawa rodzinnego instytucji rozwodu ${ }^{44}$. W konsekwencji 25 lipca 2011 r. znowelizowano kodeks cywilny ${ }^{45}$, a nowelizacja weszła w życie 1 października $2011 \mathrm{r}$.

Ostatecznie wzmocniona współpraca została uruchomiona przez 14 państw członkowskich, które przyjęły to rozporządzenie: Austrię, Belgię, Bułgarię, Hiszpanię, Francję, Luksemburg, Łotwę, Maltę, Niemcy, Portugalię, Rumunię, Słowenię, Węgry i Włochy. Później na mocy decyzji Komisji Europejskiej do wzmocnionej współpracy dołączyły: Grecja ${ }^{46}$, Estonia ${ }^{47}$ i Litwa ${ }^{48}$. Obecnie rozporządzenie jest więc stosowane w 17 państwach członkowskich.

42 K. Boele-Woelki, For Better or for Worse: The Europeanization of International Divorce Law, „Yearbook of Private International Law" 2010, vol. 12, s. 6-7, [online] https://doi.org/10.1515/97838 66539488.1.

43 P. Mostowik, Kwestia przystapienia przez Polskę do rozporzadzenia unijnego Rzym III, „Europejski Przegląd Sądowy" 2016, nr 10, s. 37.

44 Routledge Handbook of Family Law and Policy, red. J. Eekelaar, R. George, Abindgdon-New York 2014, s. 90-91.

45 Act no. XIV z 29 lipca 2011 r., zmieniajacy Kodeks Cywilny, Cap. 16, [online] http://justiceservices. gov.mt/DownloadDocument.aspx ?app=lp\&itemid=22432\&l=1, 3 VII 2018.

46 Decyzja Komisji 2014/39/UE z dnia 27 stycznia 2014 r., Dz.U. UE L 23, 28 I 2014.

47 Decyzja Komisji 2016/1366/UE z dnia 10 sierpnia 2016 r., Dz.U. UE L 216, 11 VIII 2016.

48 Decyzja Komisji 2012/714/UE z dnia 21 listopada 2012 r., Dz.U. UE L 323, 22 XI 2012. 
Majątkowe ustroje małżeńskie oraz skutki majątkowe zarejestrowanych związków partnerskich miały być początkowo uregulowane w jednym akcie prawnym. Jednak szybko okazało się, że prace nad tym rozporządzeniem będą bardzo trudne, co wynikało z odmiennego uregulowania instytucji małżeństwa w państwach członkowskich oraz z faktu, że część państw nie zna instytucji związków partnerskich, a w tych, w których ona występuje, jest różnie uregulowana. Projekt rozporządzenia został więc podzielony na dwa, różniące się między sobą zakresami zastosowania, ale podobne w odniesieniu do norm kolizyjnych i jurysdykcyjnych oraz zasad uznawania i wykonywania orzeczeń. Mimo rozbicia prac legislacyjnych na dwa projekty Rada stała na stanowisku, że państwa członkowskie powinny wyrazić zgodę na obowiązywanie obu rozporządzeń łącznie, jako że wzajemnie się uzupełniają. W odpowiedzi Polska i Węgry zawetowały przyjęcie obydwu rozporządzeń, co przesądziło o braku jednomyślności w Radzie $\mathrm{UE}^{49}$. Oba rozporządzenia mogły więc, podobnie jak rozporządzenie nr 1259/2010, zostać przyjęte jedynie w ramach wzmocnionej współpracy. Została ona uruchomiona decyzją Rady UE 9 czerwca 2016 r. ${ }^{50}$ na wniosek 18 państw. Przyjęte w ramach wzmocnionej współpracy 24 czerwca 2016 r. rozporządzenia obowiązują: Austrię, Belgię, Bułgarię, Chorwację, Czechy, Cypr, Grecję, Hiszpanię, Finlandię, Francję, Luksemburg, Maltę, Niemcy, Niderlandy, Portugalię, Słowenię, Szwecję i Włochy. Estonia zgłosiła chęć uczestnictwa we wzmocnionej współpracy, jednak oficjalna decyzja Komisji w tej sprawie jeszcze nie zapadła.

W przypadku wszystkich trzech omówionych rozporządzeń państwa nieuczestniczące we wzmocnionej współpracy mogą do niej przystąpić, gdyż jednym z warunków jej uruchomienia i późniejszego funkcjonowania jest otwartość dla wszystkich państw członkowskich $^{51}$. Dla wzmocnionej współpracy, w ramach której przyjęto rozporządzenia nr 2016/1103 i nr 2016/1104, istotne jest, że przystąpienie do niej nowych państw oznaczałoby konieczność przyjęcia obu rozporządzeń. Uczestniczenie we wzmocnionej współpracy jedynie częściowo jest bowiem wykluczone ${ }^{52}$. To szczególnie istotne dla tych państw, które - tak jak Polska - w swoich prawodawstwach nie przewidują instytucji związku partnerskiego, a tym samym niechętnie podchodzą do ewentualnego stosowania rozporządzenia dotyczącego skutków majątkowych zarejestrowanych związków partnerskich ${ }^{53}$.

49 M. Sokołowski, Stosowanie rozporządzenia nr 2016/1103 przez polskie sądy - nowe majątkowe prawo matżenskie Unii Europejskiej a sytuacja obywateli polskich, „Europejski Przegląd Sądowy” 2017, nr 11, s. 7.

50 Decyzja Rady UE nr 2016/954 z dnia 9 czerwca 2016 r., Dz.U. UE L 159, 16 VI 2016.

51 J. Sapieżko-Samordak, Wzmocniona wspótpraca w Unii Europejskiej. Koncepcja, doktryna, praktyka, Warszawa 2016, s. 80.

52 Tamże, s. 90.

53 Brak istnienia danej instytucji w przepisach prawa materialnego sam w sobie nie jest wprawdzie przeszkodą w przyjęciu norm kolizyjnych i jurysdykcyjnych dotyczących tej instytucji. Świadczy o tym choćby przykład Malty, która przyjęła rozporządzenie nr 1259/2010, lub Bułgarii, której prawo nie zna instytucji związków partnerskich, a która mimo to przyjęła rozporządzenie nr 2016/1104. 


\section{PODSUMOWANIE}

Śledząc proces przyjmowania kolejnych rozporządzeń unijnych $\mathrm{w}$ dziedzinie prawa prywatnego międzynarodowego, można zauważyć pewną tendencję. O ile prace nad pierwszymi, dotyczącymi jurysdykcji oraz uznawania i wykonywania orzeczeń w sprawach cywilnych i handlowych oraz prawa właściwego dla zobowiązań umownych i pozaumownych przebiegły dość sprawnie i szybko, o tyle prace nad kolejnymi regulacjami były już znacznie trudniejsze, a brak jednomyślności wśród państw członkowskich spowodował, że ostatnie nie mogłyby zostać przyjęte, gdyby nie uruchomiono wzmocnionej współpracy.

Taki stan rzeczy wynika przede wszystkim z faktu, że materia kolejnych rozporządzeń w coraz mniejszym stopniu dotyczyła bezpośrednio korzystania ze swobód wspólnego rynku. Transgraniczne sprawy spadkowe, małżeńskie czy alimentacyjne są oczywiście związane z przepływem osób, jednak stanowią niejako pochodną korzystania $\mathrm{z}$ tych swobód. Z kolei samo prawo rodzinne, a w pewnym stopniu także prawo spadkowe, to specyficzne dziedziny współpracy, w których należy wziąć pod uwagę daleko idące różnice prawno-kulturowe oraz interesy państw członkowskich związane z prawami podstawowymi ich obywateli ${ }^{54}$.

W odniesieniu do prawa prywatnego międzynarodowego trudno ocenić traktat lizboński jako rewolucyjny. Wręcz przeciwnie: jest on kolejnym, przewidywalnym krokiem na drodze do wypracowania przez UE kompetencji w tej dziedzinie. Trudno również zakładać, że coś w tej materii zmieni się „pod rządami” traktatu lizbońskiego; choć daje on możliwość uproszczonej zmiany traktatów i rozszerzenia kompetencji unijnych w dziedzinie spraw rodzinnych o transgranicznym charakterze, na razie wydaje się ona czysto teoretyczna, jako że zmiana w tym zakresie musiałaby zostać zaakceptowana przez wszystkie państwa członkowskie. Problemem przekraczającym ramy tego opracowania jest natomiast to, czy kompetencje Rady do przyjmowania aktów w tej dziedzinie w zwykłej procedurze ustawodawczej, a tym samym do ujednolicenia danych kwestii w skali wszystkich państw członkowskich, są faktycznie konieczne i pożądane.

\section{BIBLIOGRAFIA}

Barcz J., Problem ujednolicenia reżimu prawnego w Przestrzeni Wolności, Bezpieczeństwa i Sprawiedliwości UE - w sprawie art. 42 TUE (tzw. procedura ktadki), „Europejski Przegląd Sądowy" 2006, nr 10.

Boele-Woelki K., For Better or for Worse: The Europeanization of International Divorce Law, „Yearbook of Private International Law” 2010, vol. 12, [online] https://doi.org/ 10.1515/9783866539488.1.

Decyzja Komisji 2012/714/UE z dnia 21 listopada 2012 r., Dz.U. UE L 323, 22 XI 2012.

$54 \quad$ K. Weitz, Komentarz..., s. 1181-1182. 
Decyzja Komisji 2014/39/UE z dnia 27 stycznia 2014 r., Dz.U. UE L 23, 28 I 2014.

Decyzja Komisji 2016/1366/UE z dnia 10 sierpnia 2016 r., Dz.U. UE L 216, 11 VIII 2016.

Decyzja Rady UE nr 2016/954 z dnia 9 czerwca 2016 r., Dz.U. UE L 159, 16 VI 2016.

Konwencja o jurysdykcji i uznawaniu oraz wykonywaniu orzeczeń sadowych w sprawach cywilnych $i$ handlowych, podpisana w Lugano dnia 30 października 2007 r., Dz.U. UE L 339, 21 XII 2007.

Kowalik K., Kompetencja Wspólnoty Europejskiej w zakresie prawa prywatnego międzynarodowego, „Przegląd Sądowy” 2005, z. 2.

Lubińska K., Traktat Lizboński a wspótpraca sadowa w sprawach cywilnych, „Państwo i Prawo" 2008, z. 10.

Mostowik P., Kwestie kompetencji Unii Europejskiej oraz warunków pomocniczości i proporcjonalności prawodawstwa unijnego na tle projektów rozporządzeń o jurysdykcji, prawie wtaściwym i skuteczności zagranicznych orzeczeń $w$ majątkowych sprawach matżenskich i partnerskich, „Zeszyty Prawnicze Biura Analiz Sejmowych” 2011, nr 2.

Mostowik P., Kwestia przystąpienia przez Polskę do rozporządzenia unijnego Rzym III, „Europejski Przegląd Sądowy” 2016, nr 10.

Mostowik P., Wtadza rodzicielska i opieka nad dzieckiem $w$ prawie prywatnym międzynarodowym, Kraków 2014.

Osiejewicz J., Harmonizacja prawa państw cztonkowskich Unii Europejskiej, Warszawa 2016.

Pawlicka J., Procedura ktadki jako uproszczony tryb zmiany traktatów stanowiacych podstawe Unii Europejskiej, Warszawa 2017.

Prawo prywatne międzynarodowe, red. M. Pazdan, Warszawa 2014.

Program sztokholmski: Otwarta i bezpieczna Europa dla dobra i ochrony obywateli, Dz.U. UE C 115, 4 V 2010.

Routledge Handbook of Family Law and Policy, red. J. Eekelaar, R. George, Abindgdon-New York 2014.

Rozporzadzenie Parlamentu Europejskiego i Rady WE Nr 864/2007 z 11 lipca 2007 r. w sprawie prawa wtaściwego dla zobowiazań pozaumownych, Dz.U. UE L 199, 31 VII 2007.

Rozporządzenie Parlamentu Europejskiego i Rady WE Nr 593/2008 z 17 czerwca 2008 r. w sprawie prawa wtaściwego dla zobowiązań umownych, Dz.U. UE L 177, 4 VII 2008.

Rozporzadzenie Parlamentu Europejskiego i Rady UE z dnia 4 lipca 2012 r. w sprawie jurysdykcji, prawa wtaściwego, uznawania i wykonywania orzeczeń, przyjmowania i wykonywania dokumentów urzędowych dotyczących dziedziczenia oraz w prawie ustanowienia europejskiego poświadczenia spadkowego, Dz.U. UE L 201, 27 VII 2012.

Rozporzadzenie Rady Nr 4/2009 z dnia 18 grudnia 2008 r. w sprawie jurysdykcji, prawa wtaściwego, uznawania i wykonywania orzeczeń oraz wspótpracy $w$ zakresie zobowiązań alimentacyjnych, Dz.U. UE L 7, 10 I 2009.

Rozporzadzenie Rady UE z dnia 20 grudnia 2010 r. w sprawie wprowadzenia $w$ życie wzmocnionej wspótpracy $w$ dziedzinie prawa wtaściwego dla rozwodu i separacji prawnej, Dz.U. UE L 343, 29 XII 2010.

Rozporządzenie Rady UE z dnia 24 czerwca 2016 r. wdrażajace wzmocniona wspótpracę w dziedzinie jurysdykcji, prawa wtaściwego oraz uznawania i wykonywania orzeczeń $w$ sprawach dotyczacych matżenskich ustrojów majątkowych, Dz.U. UE L 183, 8 VII 2016. 
Sadowski W., Toborowski M., Przestrzeń wolności, bezpieczeństwa i sprawiedliwości Unii Europejskiej, cz. III: Wspótpraca sądowa w sprawach cywilnych, Warszawa 2011.

Sapieżko-Samordak J., Wzmocniona wspótpraca w Unii Europejskiej. Koncepcja, doktryna, praktyka, Warszawa 2016.

Sokołowski M., Stosowanie rozporzadzenia nr 2016/1103 przez polskie sady - nowe majatkowe prawo matżenskie Unii Europejskiej a sytuacja obywateli polskich, „Europejski Przegląd Sądowy" 2017, nr 11.

Traktat o funkcjonowaniu Unii Europejskiej (wersja skonsolidowana), Dz.U. UE C 326, 26 X 2012.

Traktat o funkcjonowaniu Unii Europejskiej. Komentarz. t. I, red. A. Wróbel, Warszawa 2012.

Traktat ustanawiający Wspólnotę Europejską (wersja skonsolidowana), Dz.U. UE C 321, 29 XII 2006.

Dr Ewa KAMARAD, asystent w Instytucie Europeistyki Uniwersytetu Jagiellońskiego. Doktor nauk prawnych ze specjalnością prawo prywatne międzynarodowe (2014), absolwentka prawa (2010) i europeistyki (2009) na Uniwersytecie Jagiellońskim. Autorka 30 publikacji. W swojej pracy naukowej zajmuje się prawem prywatnym międzynarodowym, prawem Unii Europejskiej, prawem rodzinnym, prawem konsularnym oraz międzynarodowymi stosunkami gospodarczymi. 